\title{
ANALISA ILMU ARUDH DAN QAWAFI DALAM SYAIR AL-I'TIROFKARYA ABU NAWAS
}

\author{
Moch. Sulthoni Faizin ${ }^{1}$, Ayu' Atisah ${ }^{2}$ \\ ${ }^{1,2}$ UIN Maulana Malik Ibrahim Malang \\ Email: ${ }^{1,2}$ sulthonifaizin@gmail.com
}

(Submitted: 25-11-2019, Accepted: 26-06-2020)

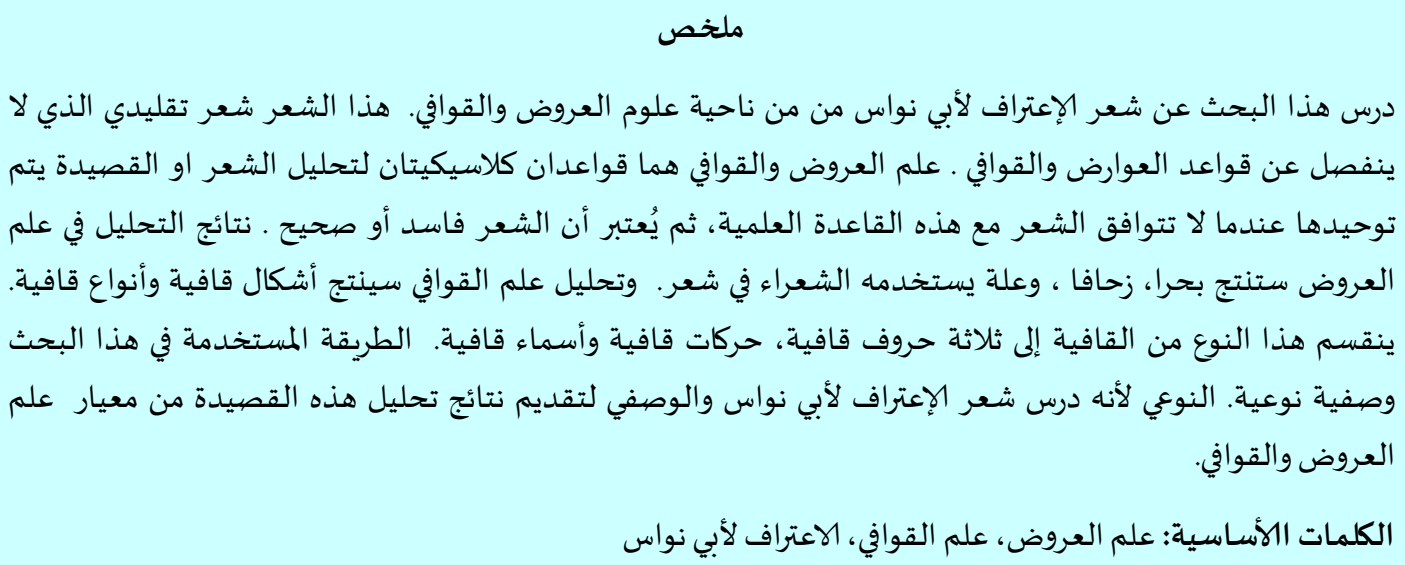

Abstract

This study analyzes the poetry of al-i'tirof by Abu Nawas in terms of arudh and Qawafi sciences. This poem is syi'rtaqlidi (ancient poetry) that is inseparable from the rules of arudh and Qawafi. The science of arudh and Qawafi are classical rules of rhythm that are standardized when a poem is not in accordance with this scientific rule, then it is considered that poetry is fasid (damaged). The results of analysis in arudh science will produce bahar, zihaf and god used by poets in a poem. And analysis of Qawafi science will produce qafiyah forms, types of qafiyah; this type of qafiyah is divided into three namely qafiyah letters, qafiyah societies and qafiyah names. The method used in this research is descriptive qualitative. Qualitative because it examines the poetry of al-i'tirof by Abu Nawas and descriptive to present the results of the analysis of this poem in terms of the science of arudh and Qawafi.

Keyword: Science of Arudh, Science of Qawafi. Poem al-i'tirof by Abu Nawas

Pengutipan: Faizin, Sulthoni dan Atisah, Ayu'. "Analisa Ilmu Arudh dan Qawafi dalam syair al-I'tirof Karya Abu Nawas" Diwan, vol. 6 no. 1 (Juni 2020). https://doi.org/10.24252/diwan.v6i1.11190 


\section{PENDAHULUAN}

Ilmu Arudh dan Qawafi merupakan dua ilmu kuno sastra Arab yang, saat ini kurang diminati oleh kalangan pelajar, karena dipandang terlalu terikat dengan aturan yang baku dan mengekang pengungkapan ekspresi dan emosi. Berbeda dengan syair modern yang banyak diminati oleh kalangan pelajar, karena sama sekali tidak terikat dengan aturan syair kuno,meskipun sebagian dari penyair modern masih menggunakan taf'ilah dan aturan Qawafi.

Namun demikian, tidak dapat dipungkiri bahwa kedua ilmu kuno ini telah menjadi mutiara dalam sejarah peradaban Arab.Seharusnya kita sebagai pelajar sastra Arab perlu memperhatikan keduailmu ini. Dari kedua ilmu ini pula, telah lahir dihadapan kita beberapa qasidah yang populer seperti Burdah karya imam Al-Bushiri dan yang berupa nadzam seperti Imrithi dan Alfiyah Ibnu Aqil.

Ilmu Arudh adalah salah satu cabang keilmuan bahasa yang membahas tentang rumus-rumus syair. Rumus syair ini menjadi patokan dalam menyusun syair maupun menganalisa syair. Syair dikatakan benaratausahih apabila syair itu mengikuti aturan yang ditetapkan dalam kaidah ilmu Arudh. Dan apabila tidak mengikuti aturan, maka syair itutergolongfasid (rusak). Dalam suatu bahar pasti terdapat wazan syair, wazan syair inilah yang menjadi patokan untuk mengikuti irama dari syair kuno. Dalam bahar juga terdapat zihaf dan ilah tertentu. Dalam ilmu Arudh terdapat pula variasi-variasi yang dapat dijadikan opsi untuk membuat syair, variasi-variasi dalam potongan syair ini adalah zihaf dan ilah. Zihaf dan ilah menjadikan potongan-potongan syair mejadi berubah dan tidak menyalahi gramatika. Zihaf dan ilah ada banyak macamnya akan tetapi tidak semua zihaf dan ilah itu dapat memasuki suatu bahar.

Dari segi rumus, syair tidak hanya dilihat dari ilmu Arudh saja, akan tetapi ujung syair juga mempengaruhi aturan penyusunan syair. Cabang keilmuan yang membahas tentang ujung syair ini disebut ilmu Qawafi. Dalam ilmu Qawafi terdapat peraturan-peraturan yang kompleks mengenai bentuk qafiyah dan jenis qafiyah.

Syair al-i'tirof karya Abu Nawas ini, sudah dikenal di kalangan umat Islam Indonesia. Beberapa banyak peneliti telah membahas tentang keindahan dari segi makna, gaya bahasa dan keindahan yang terdapat dalam syair ini. Penelitian ini ingin menelaah syair al-i'tirof ini dengan pandangan yang berbeda, dengan menggunakan ilmu Arudh dan Qawafi, dilihat dari segi tatanan rumus syairnya.

\section{METODOLOGI}

Penelitian ini termasuk penelitian kualitatif deskriptif, seperti pernyataan Moleong bahwa penelitian kualitatif adalah suatu pendekatan penelitian yang menghasilkan data yang bersifat deskriptif berupa kata-kata tertulis atau lisan, dokumen pribadi, dokumen resmi, serta catatan lapangan dari orang-orang dan perilaku yang diamati. ${ }^{1}$ Dan Burhan mengatakan penelitian deskriptif adalah peneliti yang menggambarkan suatu obyek yang

\section{3) h. 3}

${ }^{1}$ Lexy J Moleong, Metode Penelitian Kualitatif, Edisi revisi. (Bandung: PT. Remaja Rosdakarya, 
berkenaan dengan masalah yang diteliti tanpa mempersoalkan hubungan antar variabel penelitian. $^{2}$

Pendekatan kualitatif pada penelitian ini digunakan untuk memahami sebuah fakta (understanding) dan bukan menjelaskan fakta (explaining). Sehingga yang menjadi tujuan peneltian kualitatif untuk membedah secara rinci syair al-i'tirof karya Abu Nawas dari segi ilmu Arudh dan Qawafi.

\section{PEMBAHASAN}

\section{Analisis dari Segi Ilmu $A r u d h$}

Pada syair al-i'tiraf ini menggunakan bahar wafir. Terdapat taf'ilah sahih dengan taf'ilah dan ada pula yang kemasukan zihaf dan ilah. Zihaf disini hanya satu yaitu 'asb (عصاعلتن (ع) . 'Asb (عصب) merupakan salah satu dari zihaf yang kaidahnya adalah menyukunkan huruf

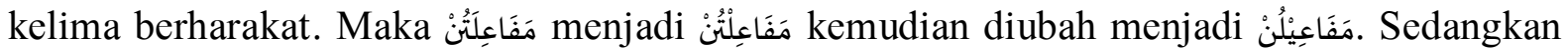
ilah disini qathf (قطف). Qathf (قطف) merupakan satu-satunya ilahyang dapat masuk pada bahar wafiryang kaidahnya adalah kumpulan dari العصب (menyukunkan huruf kelima berharakat) dan الحذف (menghilangkan sabab khafif pada akhir taf'ilah) maka menjadi

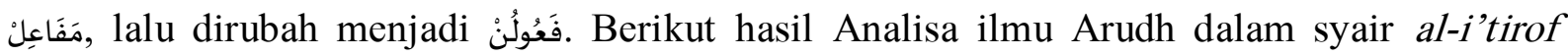
karya Abu Nawas dari segi ilmu Arudh beserta pembahasannya:

\begin{tabular}{|c|c|c|c|c|c|c|}
\hline \multirow[b]{3}{*}{ جَحَيْهِي } & \multicolumn{5}{|c|}{ شعرالاعتراف } & \multirow[b]{3}{*}{ تقطيع } \\
\hline & \multicolumn{3}{|c|}{ إِلِهِي لَسْتُ لِلْفِرْرَدَسِْ أَهْلاً } & \multicolumn{2}{|c|}{ وَلاً أَقَوى عَلَى النَّارِالجَحِيم } & \\
\hline & عَلَنْنَارِلْ & وَلََا أَقْوَى & سِاََهْلَ & تُلِلْفِرْدَوْ & إِآلَهِيلَسن & \\
\hline //o/o & $/ / 0 / 0 / 0$ & //o/o/o & //o/o & //o/o/o & //o/o/o & نُوتْت تقتيع \\
\hline فعولن & مفاعيلن & مفاعيلن & فعولن & مفاعيلن & مفاعيلن & تفعيلات \\
\hline قطف/ & عصب/ & عصب/ & قطف/ & عصب/ & عصب/ & محل التفعيلة \\
\hline مقطوفة & معصوبة & معصوبة & مقطوفة & معصوبة & معصوبة & \\
\hline
\end{tabular}

Bait pertama; semua taf'ilah pada bait ini kemasukan zihaf dan ilah dan tidak ada yang sahih, taf'ilah yang dimasuki:

Sahih (صحيح) : -

'Asb) : : : taf'ilah pertama, kedua, keempat dan kelima.

Qathf(قطف) : : taf'ilah ketiga dan keenam.

\begin{tabular}{|c|c|c|c|c|c|c|}
\hline \multirow[b]{2}{*}{ عَظظيِِْي } & \multirow[b]{2}{*}{ فِرِذذذَنْبْلْ } & \multicolumn{2}{|c|}{ فهَبْ لِي تَوْبَةً وَاغْفِرْذنوبِي } & \multicolumn{2}{|c|}{ فَإِنَّكَ غَافِرُ الذنْبِ العَظِيْيُم } & \multirow[b]{2}{*}{ تقطيع } \\
\hline & & فَفإنْنَكَغَا & ذَنُؤبِي & بَتَنْوَغَفْرِ & فَهَبْبِيْتَوْ & \\
\hline //0/0 & //o/o/o & //o///o & //o/o & //o/o/o & //o/o/o & نُوتُ تقتيع \\
\hline فعولن & مفاعيلن & مفاعلتن & فعولن & مفاعيلن & مفاعيلن & تفعيلات \\
\hline قطف/ & عصب/ & صحيح & قطف/ & عصب/ & عصب/ & محل التفعيلة \\
\hline
\end{tabular}
2001) h.54

${ }^{2}$ Burhan Bungin, Metodologi Penelitian Kualitatif dan Kuantitatif. (Yogyakarta: Gajah Mada Press, 
Moch. Sulthoni Faizin, Ayu' Atisah

Analisa Ilmu Arudh dan Qawafi dalam syair al-I'tirof Karya Abu Nawas

\begin{tabular}{|c|c|}
\hline مقطوفة & معصوية \\
\hline
\end{tabular}

Bait kedua; taf'ilah pada bait ini terdapat yang sahih dan yang kemasukan zihaf dan ilah, taf'ilah yang yang sahih dan yang dimasuki:

Sahih (صحيح) : taf'ilah keempat.

'Asb) : : : taf'ilah pertama, kedua dan kelima.

Qathf(قطف) : : taf'ilah ketiga dan keenam.

\begin{tabular}{|c|c|c|c|c|c|c|}
\hline \multirow[b]{2}{*}{ جَلَالِي } & \multirow[b]{2}{*}{ بَتَنْيَاذَلْ } & \multicolumn{2}{|c|}{ ذنوبِي مِثلُُ أَعْدَادِ الرَمَّالِ } & \multicolumn{2}{|c|}{ فَهَبَّ لِي تَوْبَةً يَاذَا الجَلالَل } & \multirow[b]{2}{*}{ تقطيع } \\
\hline & & فَهَبْبِيْتَوْْ & رمَالي & لُعَعَدَادِرْ & ذَنُؤوبِيْمِتْ & \\
\hline //o/o & //o/o/o & //o/o/o & //o/o & //o/o/o & //o/o/o & نُوتْ تقتيع \\
\hline فعولن & مفاعيلن & مفاعيلن & فـولن & مفاعيلن & مفاعيلن & تفعيلات \\
\hline قطف/ & عصب/ & عصب/ & قطف/ & عصب/ & عصب/ & محل التفعيلة \\
\hline مقطوفة & معصوبة & معصوبة & مقطوفة & معصوبة & معصوبة & \\
\hline
\end{tabular}

Bait ketiga; semua taf'ilah pada bait ini kemasukan zihaf dan ilah dan tidak ada yang sahih, taf'ilah yang dimasuki:

Sahih (صحيح) : -

'Asb : : : taf'ilah pertama, kedua, keempat dan kelima.

Qathf(قطف) : : taf'ilah ketiga dan keenam.

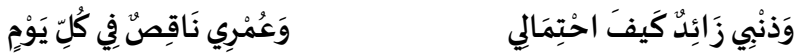

\begin{tabular}{|c|c|c|c|c|c|c|}
\hline تِمَالي & بَدِدنْكَيْفَحْ & وَذَنْبِيْزًَا & لِليَوْمِنْ & قِصَنْفِيْكُكْن & وَعَمْرَيْنَا & تقطيع \\
\hline //o/o & //o/o/o & //o/o/o & //o/o & //o/o/o & //o/o/o & نُوتْ تقتيع \\
\hline فعولن & مفاعيلن & مفاعيلن & فـولن & مفاعيلن & مفاعيلن & تفعيلات \\
\hline قطف/ & عصب/ & عصب/ & قطف/ & عصب/ & عصب/ & محل التفعيلة \\
\hline مقطوفة & معصوبة & معصوبة & مقطوفة & معصوبة & معصوبة & \\
\hline
\end{tabular}

Bait keempat; semua taf'ilah pada bait ini kemasukan zihaf dan ilah dan tidak ada yang sahih, taf'ilah yang dimasuki:

Sahih (صحيح) : -

'Asb : : : taf'ilah pertama, kedua, keempat dan kelima.

Qathf(قطف) : : taf'ilah ketiga dan keenam.

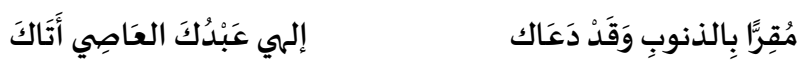

\begin{tabular}{|c|c|c|c|c|c|c|}
\hline دَعَاكًا & ذذَُُوْبَوَقَدْ & مُقِرِرَنْبِلْ & أَتَاكًا & دُكَلْعَاصِي & إِلَاَهِيْعَبْ & تقطيع \\
\hline //o/o & $/ / 0 / / / 0$ & //o/o/o & //o/o & //o/o/o & //o/o/o & نُوتْت تقتيع \\
\hline فعولن & مفاعلتن & مفاعيلن & فعولن & مفاعيلن & مفاعيلن & تفعيلات \\
\hline قطف/ & صحيح & عصب| & قطف/ & عصب/ & عصب/ & محل التفعيلة \\
\hline
\end{tabular}




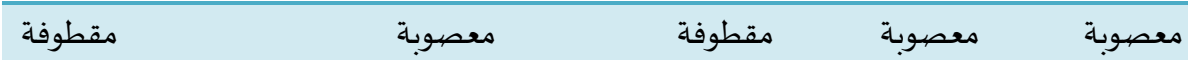

Bait kelima; taf'ilah pada bait ini terdapat yang sahih dan yang kemasukan zihaf dan ilah, taf'ilah yang yang sahih dan yang dimasuki:

Sahih (صحيح) : taf'ilah kelima.

$$
\begin{array}{ll}
\text { 'Asb } 1 \text { (عصب) } & \text { : taf'ilah pertama, kedua dan keempat. } \\
\text { Qathf(قطف) : taf'ilah ketiga dan keenam. }
\end{array}
$$

\begin{tabular}{|c|c|c|c|c|c|c|}
\hline \multirow[b]{2}{*}{ سِوَاكَا } & \multicolumn{3}{|c|}{ فَإِنْ تَغْفِرْفَفَنْتَ لذاك أَهْلُ } & \multicolumn{2}{|c|}{ فَإنْ تَطَرُدْد فَمَنْ نَرْجُوسِوَواك } & \multirow[b]{2}{*}{ تقطيع } \\
\hline & فَمَنْنَرَجُوْ & فَإِنْطَطْرُدْ & كَأَهْلُنْ & فَأَنَتَلَذَا & فَإِنْتَغْفِرْ & \\
\hline$/ / 0 / 0$ & //o/o/o & $/ / \mathrm{o} / \mathrm{o} / \mathrm{o}$ & $/ / 0 / 0$ & $/ / \mathrm{o} / / / \mathrm{o}$ & //o/o/o & نُوتْت تقتيع \\
\hline فعولن & مفاعيلن & مفاعيلن & فعولن & مفاعلتن & مفاعيلن & تفعيلات \\
\hline قطف/ & عصب/ & عصب/ & قطف/ & صحيح & عصب/ & محل التفعيلة \\
\hline مقطوفة & معصوبة & معصوبة & مقطوفة & & معصوبة & \\
\hline
\end{tabular}

Bait keenam; taf'ilah pada bait ini terdapat yang sahih dan yang kemasukan zihaf dan ilah, taf'ilahyang yang sahih dan yang dimasuki:

Sahih (صحيح) : taf'ilah (مفاعلتن) kedua.

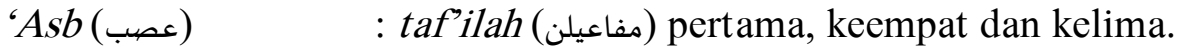

$$
\begin{aligned}
& \text { Qathf(قفف) : taf'ilah (فعولن) ketiga dan keenam. }
\end{aligned}
$$

\section{Analisis dari Segi Ilmu Qawafi}

Dari segi analisa ilmu Qawafi memunculkan dua macam analisa, yaitu dari segi bentuk qafiyah dan dari segi jenis qafiyah (huruf qafiyah, harakat qafiyah dan nama qafiyah). Dalam pembahasan di sini akan dipisahkan secara berurutan.

\section{Dari Segi Bentuk Qafiyah}

Pada syair al-i'tirof bentuk qafiyah-nya ada dua; sebagian kata dan satu kata.

\section{Sebagian kata}

Sebagian kata dalam bentuk qafiyah adalah penggalan qafiyah yang terdapat dalam syair hanya sebagian kata saja. Terdapat pada bait pertama, kedua, ketiga dan keempat; ${ }^{3}$

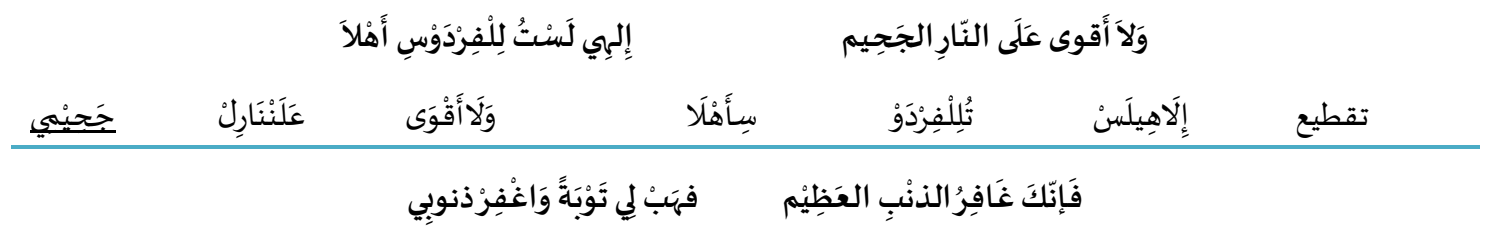

${ }^{3}$ Beberapaqafiyah yang bertambahan dengan alif-lam sebagai sebagian kata, karena dilihat dari bentuk taqti'-nya, suara lam sukun terhitung di penggalan sebelum qafiyah bukan masuk pada qafiyah, Arham, Qasidah burdah Imam Al-Bushiri (Suatu Analisis 'Ilm Al-Qawafi), Skripsi. h. 49. 
Moch. Sulthoni Faizin, Ayu' Atisah

Analisa Ilmu Arudh dan Qawafi dalam syair al-I'tirof Karya Abu Nawas

\begin{tabular}{|c|c|c|c|c|c|c|}
\hline عَظْيُهي & فِرِذْذَنْبِنْ & فَفإِنْكَكًَا & ذَنُؤُبِي & بَتَنْوَغْفِرْ & فَهَبْبلِيتَوُْو & تقطيع \\
\hline \multirow{3}{*}{ جَلَالِي } & \multirow[b]{2}{*}{ بَتَنْيَاذَلْ } & \multicolumn{2}{|c|}{ ذنوبي مِثلُ أَعْدَدَادِ الرَّمَالِ } & \multicolumn{2}{|c|}{ فَهَبْ لِي تَوْبَةً يَاذَا الجَلالَل } & \multirow[b]{2}{*}{ قطيع } \\
\hline & & فَهَبْبِيْنَتُ & رمَالي & لَالَعَدَادِز & ذُنُوْبِيْمِثْ & \\
\hline & & 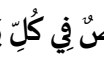 & & \multicolumn{2}{|c|}{ وَذَنْبِي زَابِدْ كَيفَ احْتِمَالِي } & \\
\hline تمَالي & يَنْدنْكَفْفَحْ & وَذَنْبِيًْا & لِيَتْوَمِنْ & 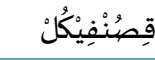 & وَعَعْمرينَنَا & تقطيع \\
\hline
\end{tabular}

\section{Satu kata}

Satu kata adalah penggalan qafiyah terdapat tepat satu kata.Terdapat pada bait kelima dan keenam;

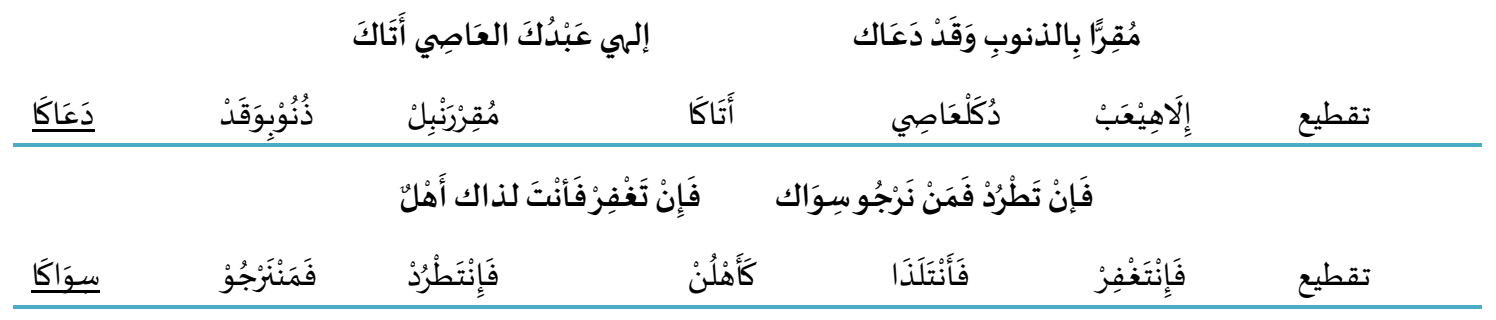

\section{Dari Segi Jenis Qafiyah}

Jenis qafiyah ini terbagi menjadi tiga; huruf qafiyah, harakat qafiyah dan nama qafiyah, yang akan dibahas secara berurutan. Pada syair al-i'tiraf ini terdapat 3 jenis huruf qafiyah yaitu:rawiy (rawiy muthlaq dan rawiy muqayyad), dan al-washal dan al-ridf.Rawiy muthlaq adalah rawiy yang terdiri dari huruf hidup (harakat). Sedangkan rawiy muqayyad adalah rawiy yang terdiri dari huruf sukun. Al-Washal adalah huruf mad (alif, ya' dan waw) yang timbul karena meng-isyba'-kan harakat rawiy atau ha' yang mendampingi rawiy.Al-Ridf, adalah huruf mad yang terdapat sebelum rawiy. Pada syair al-i'tirof ini terdapat 3 jenis harakat qafiyah yaitu; al-majra, al-hadwu dan al-tawjih. Al-Majra adalah harakat dari alrawiy muthlaq. Al-Hadhw adalah harakat huruf sebelum al-ridf. Al-Tawjih adalah harakat huruf sebelum rawiy muqayyad. Pada syair al-i'tirof ini nama syairnya ialah al-mutawatir. Al-Mutawatir; tiap-tiap qafiyah yang terdapat suatu hidup terletak di antara dua huruf sukun.

Huruf qafiyah; hasil dan pembahasannya sebagai berikut:

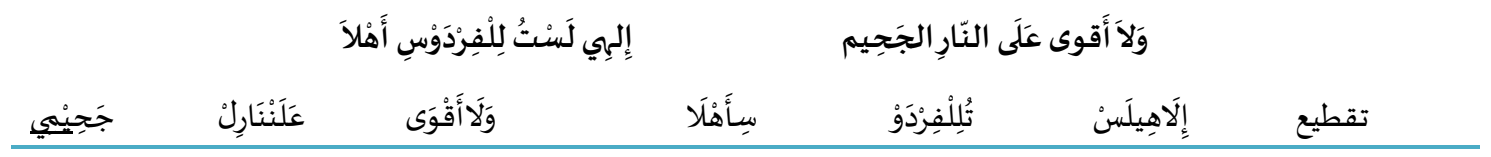

Bait pertama; huruf qafiyah dibedakan dengan warna berupa rawiy muthlaq (ungu), alwashal (biru) dan al-ridf (hijau) yang terdapat pada qafiyah جَحِيْيِي ini sebagai berikut;

Rawiy muthlaq $\quad: \operatorname{mim}($ ()

Al-Washal $\quad: y a ’($ ) 
Al-Ridf $\quad: y a^{\prime}(\mathrm{s})$

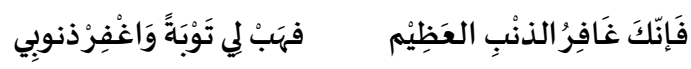

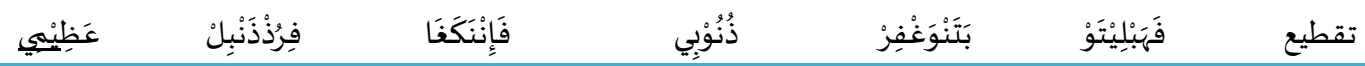

Bait kedua; huruf qafiyah dibedakan dengan warna berupa rawiy muthlaq (ungu), al-washal (biru) dan al-ridf(hijau) yang terdapat pada qafiyah عَظِيْيِي ini sebagai berikut;

Rawiy muthlaq $\quad: \operatorname{mim}(\curvearrowright)$

Al-Washal :ya'(ي)

Al-Ridf :ya'(ي)

\begin{tabular}{|c|c|c|c|c|c|c|}
\hline \multirow[b]{2}{*}{ جَلَالِي } & \multicolumn{3}{|c|}{ ذنوبِي مِثلُُ أَعْدَادِ الرَّمَالِ } & \multicolumn{2}{|c|}{ فَهَبْ لِي تَوْبَةً يَاذَا الجَلالَ } & \multirow[b]{2}{*}{ تقطيع } \\
\hline & بَتَنْيَاذَلْ & فَهَبْبِيْتَوْ & رمَالي & لُلَعَدَاَدَرْ & ذُنُوُبِيْمِثْ & \\
\hline
\end{tabular}

Bait ketiga; huruf qafiyah dibedakan dengan warna berupa rawiy muthlaq (ungu), al-washal (biru) dan al-ridf (hijau) yang terdapat pada qafiyah جََلَّini sebagai berikut;

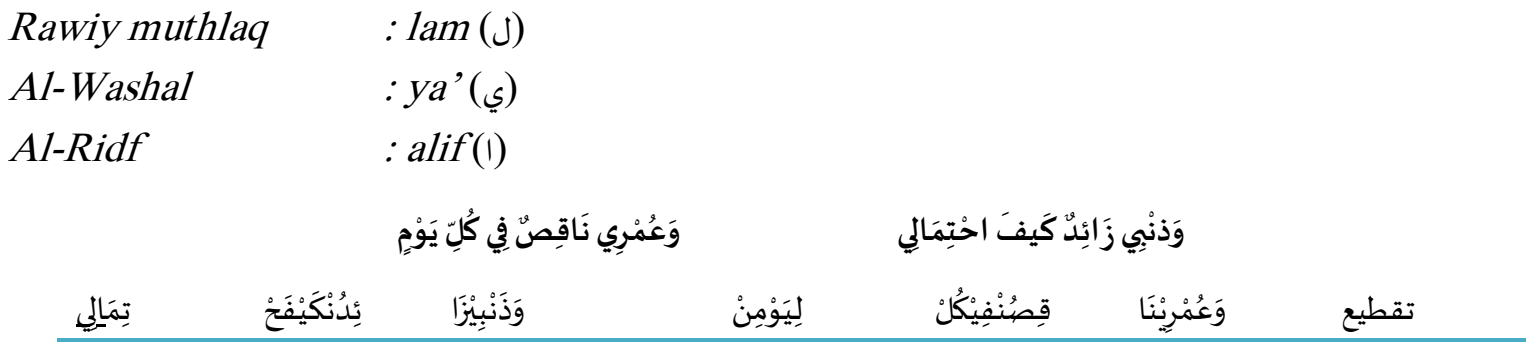

Bait keempat; huruf qafiyah dibedakan dengan warna berupa rawiy muqayyad (ungu), dan al-ridf (hijau) yang terdapat pada qafiyah تِمَالِي ini sebagai berikut;

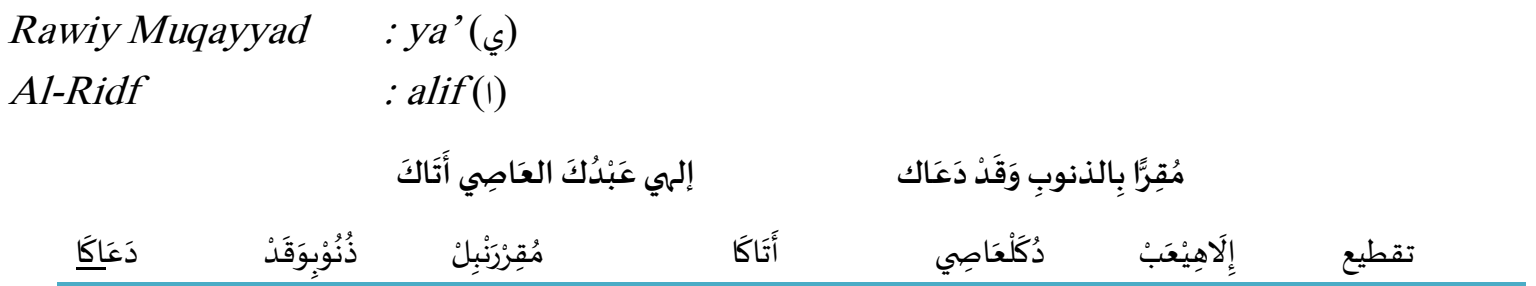

Bait kelima; huruf qafiyah dibedakan dengan warna berupa rawiy muthlaq (ungu), al-washal (biru) dan al-ridf (hijau) yang terdapat pada qafiyah دعاكا ini sebagai berikut;

$\begin{array}{ll}\text { Rawiy muthlaq } & : \operatorname{kaf}(5) \\ \text { Al-Washal } & : \operatorname{alif}(1) \\ \text { Al-Ridf } & : \operatorname{alif}(1)\end{array}$

\begin{tabular}{|c|c|c|c|c|c|c|}
\hline & & 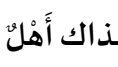 & & فْ فَمَنْ نَرْجُوسِوَاك & & \\
\hline سِِوَاكًا & فَمَنْنَرَجُوْ & فَإِنْنَطُرُدْد & كَأَهْلُنْ & فَأَنْتَلَذَا & فَاِنْنَغَفْرْ & تقطيع \\
\hline
\end{tabular}


Bait keenam; huruf qafiyah dibedakan dengan warna berupa rawiy muthlaq (ungu), alwashal (biru) dan al-ridf (hijau) yang terdapat pada qafiyah سواكا ini sebagai berikut;

$\begin{array}{ll}\text { Rawiy muthlaq } & : \operatorname{kaf}(5) \\ \text { Al-Washal } & : \operatorname{alif}(1) \\ \text { Al-Ridf } & : \operatorname{alif}(1)\end{array}$

Harakat qafiyah; berikut perinciannya:

\begin{tabular}{|c|c|c|c|c|c|c|}
\hline \multirow[b]{2}{*}{ جَحِيْيْي } & \multicolumn{3}{|c|}{ إِلِهِي ََسْتُ لِلْفِرْدَوَسِ أَهْلَاً } & \multicolumn{2}{|c|}{ وَلاَ أَقَوى عَلَى النَّارِ الجَحِيم } & \multirow[b]{2}{*}{ تقطيع } \\
\hline & عَلَنْنَارِلْ & وَلَاََقَقْوَى & سِأَهْنَا & تُلِلْفِرِدَدَوْ & إِلَاَهِيلَسن & \\
\hline
\end{tabular}

Bait pertama; harakat yang terdapat pada qafiyah جَجِيِْيْي dipandang dalam analisa harakat qafiyah;

Al-Majra : kasrahmim (2)

Al-Hadzwu : kasrah ha’ ${ }_{(\tau)}$

\begin{tabular}{|c|c|c|c|c|c|c|}
\hline \multirow[b]{2}{*}{ عَظِيْيْي } & \multirow[b]{2}{*}{ فرُذْذَنْبَلْ } & \multicolumn{2}{|c|}{ فهَبْ لِي تَوْبَةَ وَاغْفِرْذنوبِي } & \multicolumn{2}{|c|}{ فَإِنّكَ غَافِرُ الذنْبِ العَظِيْمِ } & \multirow[b]{2}{*}{ تقطيع } \\
\hline & & فَاِنَنَكَغًَا & ذُنُوُوْبي & بَتَنْوَغْفِرْ & فَهَبْبِلِيَتَوْ & \\
\hline
\end{tabular}

Bait kedua; harakat yang terdapat pada qafiyah عَظِيْمي dipandang dalam analisa harakat qafiyah;

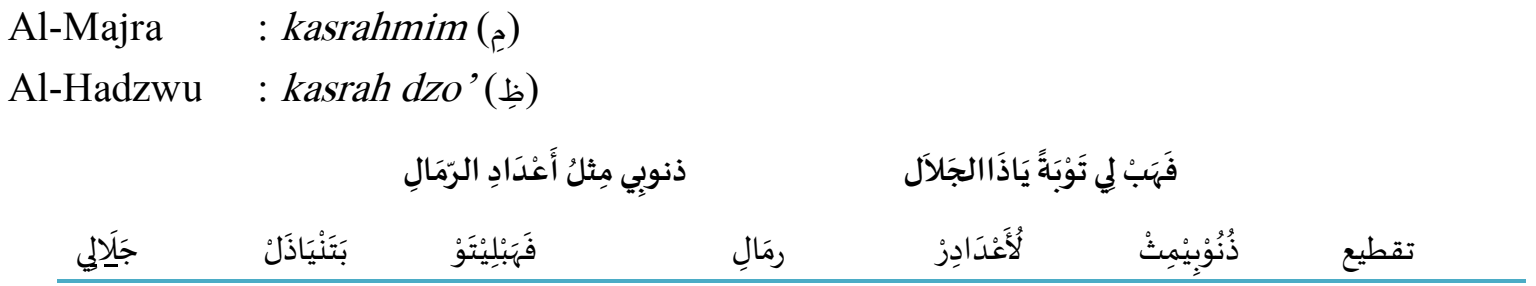

Bait ketiga; harakat yang terdapat pada qafiyah جََلَّل dipandang dalam analisa harakat qafiyah;

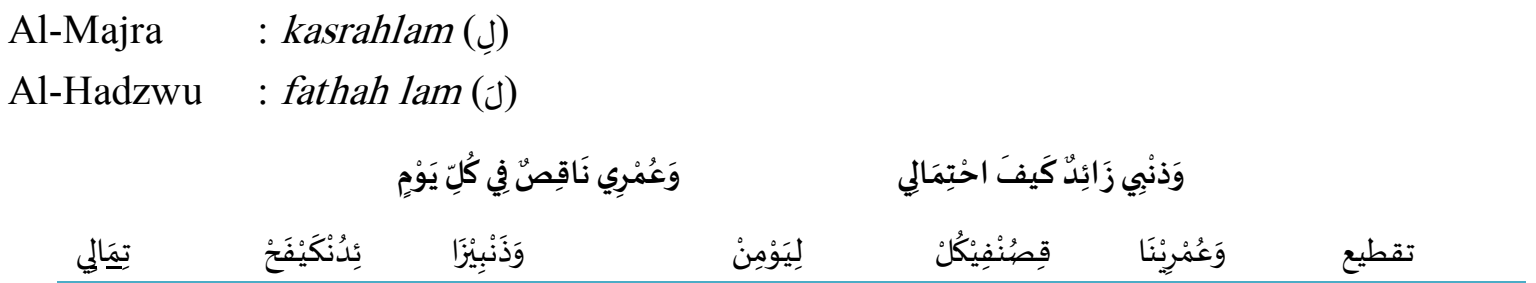

Bait keempat; harakat yang terdapat pada qafiyah dِمَالِن dipandang dalam analisa harakat qafiyah;

Al-Hadzwu : fathah mim (广) 
Al-Tawjih : kasrah lam (J)

إلهي عَبُْدُكَ العَاصِي أَتَكَكَ

مُقِرًِا بِالذنوبِ وَقَدْد دَعَاك

دَعَاكَا

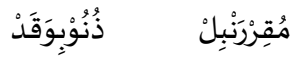

أَتَكاكَا

دُكَلْعَاِِي

تقطيع إِلَآهِيْعَبْ

Bait kelima; harakat yang terdapat pada qafiyah دعاكا dipandang dalam analisa harakat qafiyah;

Al-Majra : fathah kaf(

Al-Hadzwu : fathah 'ain (c)

فَإِنْ تَطْرُدْ فَمَنْ نَرَجُوسِوَاك

تقطيع

Bait keenam; harakat yang terdapat pada qafiyah سواكا dipandang dalam analisa harakat qafiyah;

Al-Majra : fathah kaf(⿶)

Al-Hadzwu : fathah wawu(g)

Nama qafiyah; analisanya sebagai berikut:

\begin{tabular}{|c|c|c|c|c|c|c|}
\hline \multirow[b]{2}{*}{ جَحَيْيِْي } & \multicolumn{3}{|c|}{ إِلِهِي لَسْتُ لِلْفِرِدَوَسِْ أَهْلَاً } & \multicolumn{2}{|c|}{ وَلاَ أَقَوى عَلَى النّارِ الجَحِيم } & \multirow[b]{2}{*}{ تقطيع } \\
\hline & عَلَنْنَارِلْ & وَلَاَأَقْوَى & سِأَهَنَ & تُلِلْفِرْدَدوْ & إِلَاهِيلَسن & \\
\hline
\end{tabular}

Bait pertama; pada bait ini dalam qafiyah (جحيمي) terdapat huruf hidup mim berharakat kasrah (مِ) di antara dua sukun ya’ (ي) sebelum mim dan ya’ (ئ) setelah mim.

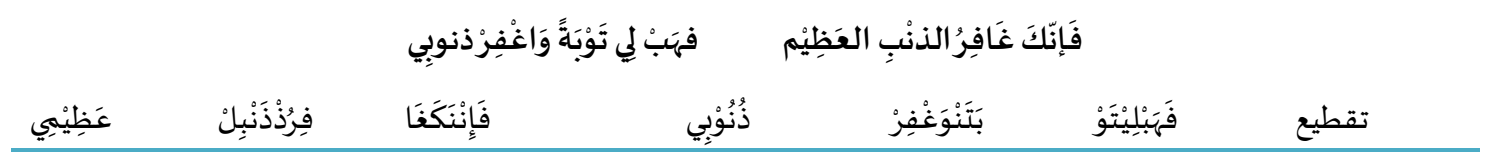

Bait kedua; pada bait ini dalam qafiyah (عظيمي) terdapat huruf hidup mim berharakat kasrah (م) di antara dua sukun ya' (ي) sebelum mim dan ya’'(ي) setelah mim.

\begin{tabular}{|c|c|c|c|c|c|c|}
\hline \multirow[b]{2}{*}{ جَلَلالي } & \multicolumn{3}{|c|}{ ذنوبِي مِثِلُ أَعْدَادِ الرَّمَالِ } & \multicolumn{2}{|c|}{ فَهَبْ لِي تَوْبَة يَاذَا الجَلَلَل } & \multirow[b]{2}{*}{ نقطيع } \\
\hline & بَتَنْيَاذَلْن & فَهَبْبِلِيَتَوْ & رمَالِ & لُعَعَدَا دِرْ & ذُنُوُبِيْمِمِ & \\
\hline
\end{tabular}

Bait ketiga; pada bait ini dalam qafiyah (جلالي) terdapat huruf hidup lam berharakat kasrah (ل) diantara dua sukun alif(।) dan ya’’ (ي).

\begin{tabular}{|c|c|c|c|c|c|c|}
\hline \multirow[b]{2}{*}{ تِمَالِي } & \multicolumn{3}{|c|}{ وَعُمْرِي نَاقِصن فِي كُلِّ يَوٍِْ } & \multicolumn{2}{|c|}{ وَذْنْبِي زَائدُ كَيفَ احْتِمَالِي } & \multirow[b]{2}{*}{ تقطيع } \\
\hline & 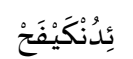 & وَذَنَنْبِيًْا & لِليَوْمنْن & قِصِنْنْفِيْكُكن & وَعَعْمِنْنَا & \\
\hline
\end{tabular}


Bait keempat; pada bait ini dalam qafiyah (تمالي) terdapat huruf hidup lam berharakat kasrah

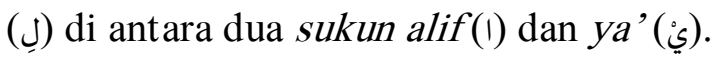

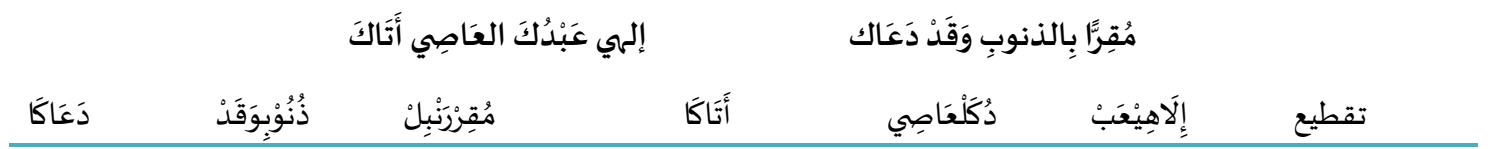

Bait kelima; pada bait ini dalam qafiyah (دعاك) terdapat huruf hidup kaf berharakat fathah (ك) di antara dua sukun alif(।) sebelum kafdan alif(।) setelah kaf.

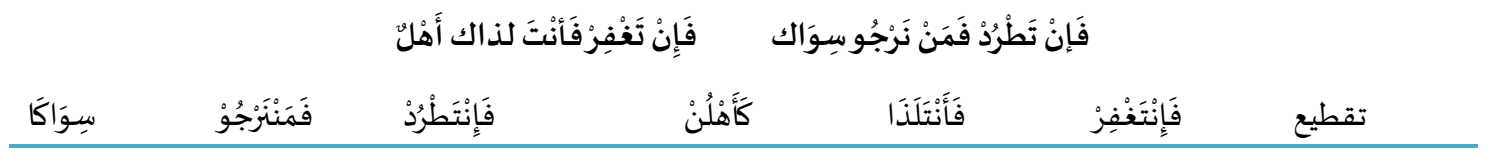

Bait keenam; pada bait ini dalam qafiyah (سواكا) terdapat huruf hidup kaf berharakat fathah (अ) di antara dua sukun alif(।) sebelum kafdan alif(।) setelah kaf.

\section{PENUTUP}

Analisis syair al-'tirof (bahar wafir) ini bahwa dari segi ilmu Arudh wazannya sahih tidak fasid (rusak) baik dari segi zihaf maupun ilah-nya. Sebagian ulama ahli Arudh mengatakan bahwa semakin banyak mencampuradukkan zihaf dan ilah yang bermacam-macam dapat mengurangi keindahan syair ketika diucapkan. Dan dalam syair ini zihaf yang digunakan hanya 'asb,ilah yang digunakan qathf, dan sebagian taf'ilah kedudukannya sahih. Segi ilmu Qawafi analisis syair al-i'tirof dibagi dua macam, bentuk Qawafi dan jenis qafiyah. Segi bentuk terdapat sebagian kalimat dan satu kalimat. dari segi jenis qafiyah masih dibagi lagi menjadi 3; huruf qafiyah, harakat qafiyah dan nama qafiyah. Huruf qafiyah terdapat tiga macam; rawiy (rawiy muthlaq dan rawiymuqayyad), al-washal dan al-ridf. Huruf qafiyah terdapat 3; al-majra, al-hadwu dan al-tawjih. Dan nama qafiyah; Al-Mutawatir, tiap-tiap qafiyah yang terdapat suatu hidup terletak diantara dua huruf sukun. Dengan kedua sisi analisa ini kita dapat mengetahui keindahan syair al-i'tirof karya Abu Nawas dari segi ilmu Arudh dan Qawafi.

\section{DAFTAR PUSTAKA}

Ad-Damanhuri, Muhammad, Al-Mukhtasar Asy-Syafi 'ala Matan Al-Kafi. Surabaya: Hidayah. 2010.

Al-Hasyimi, Ahmad. Mizan Al-Dhahab fi Sina'at Syi’r Al-'Arabi. Mesir: Maktabah AlTijariyyah Al-Kubra. 2006.

Al-Hasyimi, Ali Al-Arudh Al-Qadlih wa Ilmu Al-Qawafiyah. Damaskus: Dar al-Qalam. 1991.

Asyura, Muhammad. Al-Manhaj Ash-Shafi fi Al-Arudh wa Al-Qawafi. Kairo: Mathba'ah Al-Amanah. 1989.

Al-Haditsi, Bahjat Abdul Ghafur. Diwan Abi Nuwas bi Riwayat Ash-Shuly. Abu Dhabi: AlMujma' Ats-Tsaqafi. 2010

Hamid, Mas'an. Ilmu Arudh dan Qawafi. Surabaya: Al-Ikhlas. 1995 
Ibnu Hani', Abu Nawas al-Hasan. Diwan Abi Nuwas. Bairut: Dar al-Shadir, tth.

Ibnu Ustman, Muhammad bin Hasan. Mursyid Al-Kafi fi al-Arudh wa Al-Qawafi. Dar alThaba'ah al-Muhammadiyah: Kairo. 1991.

Munawwir, Achmad Warson. Kamus Al-Munawwir Arab-Indonesia Terlengkap. Surabaya: Pustaka Progressif. 1997.

Salim, Abdullah Amin. Al-Arudh wa Al-Qafiyah. Penerbit: Jami'ah Al-Imam Muhammad ibn Saud al-Islamiyah. 1998.

Zaenuddin, Mamat. Karakteristik Syi'r Arab. Bandung: Zain Al-Bayan. 2007. 